\title{
ОЦІНКА РЕЗУЛЬТАТІВ УЛЬТРАЗВУКОВОГО ДОСЛІДЖЕННЯ СТАНУ IШЕМІЗОВАНИХ М'ЯЗІВ КІНЦІВОК У ХВОРИХ З НАСЛІДКАМИ КОМПАРТМЕНТ СИНДРОМУ
}

\author{
О. В. Долгополов, О. С. Страфун, В. А. Боєр \\ Інститут травматології та ортопедії НАМН України, м. Київ

\section{EVALUATION OF THE RESULTS OF SONOGRAPHIC STUDY OF ISCHEMIZED EXTREMITY MUSCLES IN PATIENTS WITH THE CONCEQUENCES OF THE COMPARTMENT SYNDROME}

\author{
O. V. Dolgopolov, O. S. Strafun, V. A. Boier \\ Institute of Traumatology and Orthopaedics, Kyiv
}

\section{Реферат}

Проаналізовані результати ультразвукового дослідження (УЗД) 653 м'язів кінцівок у 69 хворих за ішемічної контрактури (ІК) в реактивно-відновному періоді. Для кількісної оцінки стану м'язів розроблені спеціальні комп'ютерні програми визначення їх некрозу та $\delta$-ентропії. Встановлене збільшення частки некрозу в ішемізованих м'язах у міру збільшення тяжкості ІК. Показники вертикальної $\delta$-ентропії ішемізованих м'язів вірогідно менші, ніж інтактних м'язів за ІК тяжкої та середньої тяжкості; показники горизонтальної б-ентропії ішемізованих м'язів, навпаки, вірогідно більші, ніж в інтактних м'язах, за ІК тяжкої (достовірно) і середньої тяжкості. Встановлений вірогідний позитивний зв'язок між тяжкістю ІК та часткою некрозу м'язів. За допомогою регресійного аналізу встановлений обернений кореляційний зв'язок між часткою некрозу і показниками $\delta$-ентропії, особливо ішемізованих м'язів. Низькі показники $\delta$-ентропії (вертикальної і горизонтальної) свідчать про значний некроз ішемізованих м'язів, що має суттєве діагностичне значення.

Ключові слова: ішемічна контрактура; зміни м'язів кінцівок; ультразвукове дослідження; кількісна оцінка результатів.

Abstract

We analyzed the results of sonographic study of 653 muscles in 69 patients with ischemic contracture (IC) in reactive-restoration period. Special computer programs evaluating tissue necrosis and $\delta$-enthropy were elaborated in order to perform quantitative assessment of the muscle status. Increased necrotic part in the ischemized muscles correlated with the IC severity. Indicators of vertical $\delta$-enthropy of ischemized muscles were significantly lower than in the intact muscles in severe and middle IC. Horizontal $\delta$-enthropy indicators in the ischemized muscles, on the contrary, were significantly higher than in the intact muscles. We established significant positive connection between the severity of IC and the part of muscle necrosis. Using the regression analysis we established reverse correlation between the part of necrosis and $\delta$-enthropy indicators, especially in the ischemized muscles. Low indicators of $\delta$-enthropy (both vertical and horizontal) are the evidence of significant necrosis of the ischemized muscles, which has essential diagnostic significance.

Keywords: ischemic contracture; extremities' muscle changes; sonography; quantitative analysis.

Лікування ІК кисті і стопи (контрактури Фолькмана) є складною проблемою травматології та ортопедії. ІК формується у 4 - 6\% потерпілих при переломах кісток кінцівок [1, 2], поряд 3 медичним аспектом, це має важливе соціальне значення у зв'язку з значним порушенням функції кінцівок та інвалідизацією хворих. Проблемі посттравматичної ішемії тканин кінцівок присвячені численні дослідження, проте, питання діагностики стану ішемізованих м'язів, оборотності чи необоротності змін цих тканин, особливостей їх структури не вирішені [3, 4]. При аналізі даних сучасної літератури виявлені лише поодинокі повідомлення, присвячені УЗД м'язів при ІК, що здебільшого стосуються діагностиці міс- цевого гіпертензивно-ішемічного синдрому $[2,4,5]$.

Нами раніше вивчені за даними УЗД структурні зміни в м'язах хворих при посттравматичній ІК кисті і стопи залежно від тяжкості ішемічного ураження, тривалості патологічного процесу, наявності травматичного пошкодження периферійних нервів. Визначені характерні особливості ішемічних змін м'язів на початку реактивно-відновного періоду у вигляді деструктурованості, неоднорідності змін, наявності гіпоехогенних вогнищ некрозу та гіперехогенних зон, оцінка яких була переважно якісною [2].

Однією 3 важливих характеристик неживих та живих систем, 3 точки зору фізики, є ентропія. Поняття «ентропія» (поворот, перетворення) як міру необоротного розсіювання енергії широко застосовують в термодинаміці, а також інших галузях, у статистичній фізиці - як міру можливості здійснення будь-якого макроскопічного стану, в теорії інформації - як міру невизначеності будь-якого досліду, що може мати різні наслідки [6].

Поняття ентропії, як вперше показав Е. Шредингер (1944), суттеве і для розуміння життя. Живий організм 3 точки зору фізико-хімічних процесів, що відбуваються в ньому, можна розглядати як складну відкриту систему, вона перебуває у нерівномірному, проте, стаціонарному стані. Для організмів характерна збалансованість процесів, що зумовлюють 
збільшення ентропії, та процесів обміну, що зменшують іiі. Проте, життя не обмежується сукупністю фізикохімічних процесів, йому притаманні складні процеси саморегулювання. Тому за допомогою поняття ентропії неможливо охарактеризувати життєдіяльність організмів в цілому [6]. Проте, застосування ультразвукового показника $\delta$-ентропії може мати певні перспективи для діагностики й прогнозування під час дослідження стану м'язів ішемізованих кінцівок.

У спеціальній літературі ми не знайшли даних про спроби використання цього показника 3 діагностичною метою.

Мета дослідження: визначити стан ішемізованих м'язів кінцівок у хворих 3 наслідками компартмент синдрому на підставі оцінки кількісних показників УЗД.

\section{МАТЕРІАЛИ I МЕТОДИ ДОСЛІДЖЕННЯ}

Для УЗД взяті 653 м'язи у 69 хворих, оперованих з приводу компартмент синдрому з подальшим формуванням ІК кисті і стопи, які перебували у реактивно-відновному періоді. Тяжкість ІК кисті оцінювали за класифікацією С. С. Страфуна, стопи за класифікацією А. П. Лябаха [7].

УЗД проводили за допомогою апарата НДІ 3500 та НД 11 XЕ (Philips) 3 мультичастотними лінійними датчиками з частотою $5-12$ МГц 3 використанням стандартних методик [3, 4, 7]. Дослідження проводили у двох площинах - вертикальній та горизонтальній. 3 метою стандартизації умов та результатів дослідження місце розташування датчика встановлювали шляхом визначення його положення щодо певних координат кінцівки (суглобової щі- лини, кісткових орієнтирів), що дозволяло оцінювати результати в динаміці. Стандартизацію місця розташування датчика на передпліччі досягали також застосуванням спеціальних лекал, що накладали однаково на уражену та інтактну кінцівки [2]. Визначали якісні та кількісні ультразвукові параметри м'язів ураженої та інтактної кінцівок. Параметри УЗД оцінювали з використанням як абсолютних значень, так і відносних - відсоток від норми. За норму приймали показники інтактних м'язів контралатеральної кінцівки. Аналіз ультразвукової структури проводили у В-режимі.

Вивчали кількісні показники (для яких розроблена спеціальна комп'ютерна програма): частка некрозу ішемізованого м'яза (\% від норми), показники вертикальної та горизонтальної $\delta$-ентропії (умовні одиниці) [2].

Результати оброблені за допомогою параметричних методів статистики. Для визначення зв'язку кількісних показників УЗД і тяжкості ішемії використовували кореляційний (коефіцієнт кореляції та кореляційне відношення) та регресійний аналіз. При обчисленні кореляції тяжка ішемія відповідала умовно 3 балам, середньої тяжкості - 2 бала, легка - 1 бал. Вірогідність різниці середніх оцінювали за крітерієм ФішераСт'юдента.

\section{РЕЗУЛЬТАТИ \\ ТА ÏХ ОБГОВОРЕННЯ}

Для обробки і аналізу використані кількісні показники УЗД 653 м'язів верхніх і нижніх кінцівок у 69 хворих за наявності ІК у реактивно-відновному періоді (табл. 1). Частка некрозу ішемізованих м'язів збільшу- валася у міру збільшення тяжкості IК. За тяжкої ІК вона у 4 рази перевищувала таку за легкої ІК ( $>$ < 0,001) та утричі - за ІК середньої тяжкості; за ІК середньої тяжкості - також достовірно перевищувала таку за легкої ІК ( $>$ < 0,001). Ці результати свідчать про значний вплив тяжкості ІК на виникнення некрозу м'язів.

Показники горизонтальної $\delta$-ентропії перевищували такі вертикальної ентропії за всіх ступенів тяжкості IK, найбільший показник в усіх групах відзначали за ІК середньої тяжкості ( $\mathrm{p}<0,05$; $\mathrm{p}<0,001)$, показник горизонтальної $\delta$-ентропії - за легкої ІК.

Аналізуючи вплив тяжкості ІК на зміни показників ентропії, слід відзначити:

- тільки за легкої ІК показники горизонтальної та вертикальної $\delta$-ентропії були більшими на ішемізованому боці;

- парадоксально, але показник горизонтальної $\delta$-ентропії вірогідно зменшувався у міру збільшення тяжкості ІК ( $p<0,001 ; \mathrm{p}<0,05)$ і був найменшим за тяжкої ІК на ішемізованому боці;

- показники вертикальної $\delta$-ентропії ішемізованих м'язів також були вірогідно меншими, ніж на інтактному боці, за ІК тяжкої та середньої тяжкості $(\mathrm{p}<0,01)$;

- показники горизонтальної $\delta$ ентропіі ішемізованих м'язів перевищували такі на інтактному боці за ІК усіх ступенів тяжкості (достовірно - за легкої та тяжкої ІК, $\mathrm{p}<0,01)$, що $є$ позитивним в діагностичному плані.

Виявлення на ішемізованому боці 50\% і більше некрозу в м'язах і збільшення показника горизонтальної $\delta$ ентропії (при зменшенні показни-

Таблиця 1. Кількісні показники УзД м'язів кінцівок у хворих з наслідками компартмент синдрому у реактивновідновному періоді

\begin{tabular}{|c|c|c|c|}
\hline \multirow{2}{*}{ Показник УзД } & \multicolumn{3}{|c|}{ Величина показника за ступеня тяжкості IK $(\bar{x} \pm \mathrm{m}))$} \\
\hline & тяжкої & середньої тяжкості & легкої \\
\hline Частка некрозу ішемізованих м'язів, \% & $\begin{array}{c}54,09 \pm 1,3 \\
(n=264)\end{array}$ & $\begin{array}{c}18,29 \pm 0,80 * \\
(n=281)\end{array}$ & $\begin{array}{c}12,14 \pm 0,82^{* 4} \\
(n=108)\end{array}$ \\
\hline \multicolumn{4}{|l|}{ Інтактний бік } \\
\hline б-ентропія горизонтальна, ум. од. & $4,58 \pm 0,08$ & $6,18 \pm 0,06 *$ & $5,98 \pm 0,08 * \Delta$ \\
\hline б-ентропія вертикальна, ум. од. & $8,55 \pm 0,008$ & $10,32 \pm 0,09 *$ & $9,23 \pm 0,16^{* \Delta}$ \\
\hline \multicolumn{4}{|l|}{ Уражений бік } \\
\hline б-ентропія горизонтальна, ум. од. & $4,94 \pm 0,13$ & $6,47 \pm 0,18^{*}$ & $6,62 \pm 0,08^{* \Delta}$ \\
\hline б-ентропія вертикальна, ум. од. & $6,8 \pm 0,02$ & $10,04 \pm 0,06 *$ & $9,44 \pm 0,09 * \Delta$ \\
\hline
\end{tabular}

Примітка. Різниця показників вірогідна порівняно з такими: ${ }^{*}-$ за тяжкої ІК; ${ }^{\Delta}-$ за ІІ середньої тяжкості $(p<0,05-0,001)$. 
ка вертикальної $\delta$-ентропіі) в порівнянні з такими на неураженому боці свідчить про наявність тяжкої ІК. Для легкої ІК характерне незначне збільшення показників горизонтальної та вертикальної $\delta$-ентропії та велика частка некрозу в ішемізованих м'я$3 a x-10-13 \%$.

Показники горизонтальної та вертикальної $\delta$-ентропії змінюються в м'язах ішемізованого боку за ІК тяжкої та середньої тяжкості в протилежному напрямку, ніж за легкої ІК; для тяжкої ІК характерні найменші показники. Можливо, зменшення показника вертикальної $\delta$-ентропії зумовлене більшою структурною однорідністю внаслідок переважно тотального (субтотального) некрозу за тяжкої ІК в порівнянні з «мозаїчним некрозом м'язів - за легкої IК. Аналіз індивідуальних показників у хворих за ІК різної тяжкості підтверджує це припущення. Так, у хворого Б. за тяжкої ІК тотальний некроз ішемізованого м'яза (96\%) супроводжувався показниками горизонтальної $\delta$-ентропії 0,64, вертикальної - 1,45. У хворої К. за легкої ІК частка некрозу становила 3\%, показники горизонтальної $\delta$-ентропії - 8,41, вертикальної - 11,0. Різноспрямовані зміни середніх показників вертикальної та горизонтальної $\delta$-ентропії при ІК різної тяжкості ускладнюють застосування цих показників у діагностичному плані та потребують подальшого дослідження.

Показники ентропії збільшуються при переході речовини у стан 3 більшою енергією (відповідно, вони менші за стану речовин з меншою енергією). Також, чим більша щільність речовини, тим менші показники іiі ентропії. Ці дані дозволяють пояснити збільшення показників ентропії в інтактному м'язі (збільшення енергії при компенсаторному навантаженні) при збільшенні частки некрозу м'яза ішемізованої кінцівки, а також зменшення показників ентропії ішемізованого м'яза за знач-

Таблиця 2. Результати кореляційного аналізу зв'язку показників тяжкості ІК і частки некрозу м'язів кінцівок у хворих в реактивно-відновному періоді

\begin{tabular}{|ccc|}
\hline Коефіцієнт кореляції $(\mathrm{m} \pm \mathrm{s})$ & Кореляційне відношення $\left(\eta_{\mathrm{xy}} \eta_{\mathrm{yx}}\right)$ \\
\hline $0,71 \pm 0,028$ & 0,74 \\
\hline $\mathrm{p}<0,001$ & 0,81 \\
\hline \multicolumn{3}{c}{ Коефіцієнти детермінації } \\
\hline 0,504 & 0,548 \\
\hline
\end{tabular}

мий зв'язок між тяжкістю ІК і кількісним УЗД показником - часткою некрозу м'язів як показника структурованості м'язової тканини. Ці особливості найбільш чітко проявляються за тяжкої та легкої ІК, меншою мірою - при ІК середньої тяжкості.

3 огляду на нелінійний характер зв'язку тяжкості ІК та кількісних показників УЗД, що видно з порівняння коефіцієнта кореляції та кореляційного відношення, а також змін середніх показників УЗД за різної тяжкості ІК, для уточнення цього зв'язку застосований регресійний аналіз.

Використана формула для нелінійній регресії, виразом якої $є$ рівняння гіперболи першого порядку. Перевірений зв'язок між кількісними показниками УЗД: часткою некрозу м'язу і горизонтальної та вертикальної $\delta$-ентропії ішемізованих м'язів та м'язів інтактного боку. В результаті рішення рівнянь отримали такі дані:

горизонтальна $\delta$-ентропія $\dot{Y}_{1}=5,445+4,318 / 31,7=5,58(y=5,70)$ (інтактний бік)

вертикальна $\delta$-ентропія

$\dot{Y}_{2}=9,565+2,776 / 31,7=9,65(y=9,72)$ (інтактний бік)

горизонтальна $\delta$-ентропія $\dot{Y}_{1}=5,577+5,405 / 31,7=5,75(\mathrm{y}=5,87)$ (уражений бік)

вертикальна $\delta$-ентропія ${ }_{4}=$ $8,149+9,265 / 31,7=8,44(\mathrm{y}=8,66)$ (уражений бік) лено, що коефіцієнт детермінації кореляційного відношення перевищує коефіцієнт детермінації коефіцієнта кореляції, різниця між ними більша за 0 , що свідчить про нелінійний зв'язок між досліджуваними ознаками. Величина коефіцієнта детермінації також підтверджує кореляційний зв'язок середньої сили між зазначеними показниками (табл. 2).

В цілому, результати кореляційного аналізу підтверджують достовірність змін кількісних показників УЗД в умовах впливу тяжкості ішемії на структуру ішемізованих м'язів, а також свідчать про достовірний пря-

У дужках наведені дослідні результати.

Показники регресії виявляють кореляційний зв'язок двобічно, з огляду на зміни середніх значень у́ ознак У при змінах значень х ознаки X i, навпаки, показують зміни середніх значень х ознаки Х за змінами значень у́ ознаки У. Оскільки основним аргументом - визначальним чинником структурних змін м'яза, наслідком якого є зміни $\delta$-ентропії, при ІК $€$ частка некрозу, ми вивчали тільки однобічну регресію: зміни показників $\delta$-ентропії залежно від змін частки некрозу.

Подальша перевірка шляхом порівняння показників $\delta$-ентропіi, розрахованих за рівнянням гіперболи першого порядку, та показників, отриманих з графічних ліній регресії, показала, що в межах 10 - 50\% некрозу ці показники майже однакові. Найбільш близькими були показ- 
ники горизонтальної $\delta$-ентропії (як ішемізованих, так і інтактних м'язів). За більш значної частки некрозу розбіжності цих показників більші.

Отриманні в результаті регресійного аналізу дані свідчать про наявність оберненого кореляційного зв'язку між часткою некрозу м'яза і показниками вертикальної та горизонтальної $\delta$-ентропії, особливо ішемізованих м'язів. Залежність показників $\delta$-ентропії від частки некрозу ішемізованих м'язів найбільш значна при некрозі понад 50\%, тотальному й субтотальному некрозі м'язів. Цей парадоксальний, на перший погляд, факт, можливо, зумовлений фізичними особливостями розсіювання та відбиття ультразвукового сигналу у некротизованій ткани-

\section{ЛITEPATУPA/REFERENCES}

1. Kopytchak YR. Kliniko-morfolohichni osoblyvosti ta likuvannia perelomiv homilky u postrazhdalykh z politravmoiu [avtoreferat]. Kyiv, 2011. 20 s. [In Ukrainian].

2. Strafun SS, Haiko OH, Dolhopolov OV, Mazevych VB. Sonohrafiia $\checkmark$ diahnostytsi posttravmatychnykh ishemichnykh ushkodzhen kintsivok. Visnyk ortopedii, travmatolohii ta protezuvannia. 2015;(2):812. [In Ukrainian].

3. Strafun SS, Brusko AT, Liabakh AP, ta in. Profilaktyka, diahnostyka ta likuvannia ishemichnykh kontraktur kysti ta stopy. Kyiv: Stylos, 2007. 264 s. [In Ukrainian].

4. Strafun SS, Hrytsai MP, Vovchenko AYa, ta in. Ultrazvukova diahnostyka pisliatravmatychnykh ishemichnykh ushkodzhen homilky vnaslidok perelomu yii kistok. Visnyk ortopedii, travmatolohii ta protezuvannia. 2008;(3);56-60. [In Ukrainian]. ні. В діагностичному аспекті суттеве зменшення показників $\delta$-ентро(менше 3 - 4 ум. од.) свідчило про нини.

Отримані нами результати узгодморфологічних змін ішемізмін показників $\delta$ к кінцівок

Аналіз отриманих результатів свідчить, що впровадження розробленої спеціальної комп'ютерної програми дозволяє кількісно оцінити за даними УЗД стан м'язів ішемізованої та інтактної кінцівок у хворих 3 наслідками компартмент синдрому в реактивно-відновному періоді ІК Це сприятиме вибору тактики лікування й адекватному рішенню щодо транслокації (транспозиціі) м'язів та м'язово-тканинних трансплантатів.

Результати роботи підтверджують наші попередні дані про залежність структурно-функціонального стану ішемізованих м'язів від тяжкості ІК в реактивно-відновному періоді.

На підставі кількісних показників УЗД можлива ретроспективна оцінка тяжкості компартмент синдрому та певний прогноз результатів лікування.
5. Malcus CM, Siener ES. Qualitative and quantitative skeletal muscle ultrasound in late onset acid maltase deficiency Sandman Muscle Were. 2011;44(3):418-3.

6. Freik ND, Tsymbrykevych YK. Entropiia i filosofski aspekty zhyvoho. Fizyka i khimiia tverdoho tila. 2011;12(4):1107-11. [In Ukrainian].

7. Liabakh AP, Vovchenko AYa. Zastosuvannia ultrazvukovoho doslidzhennia $v$ otsintsi strukturno-funktsionalnoho stanu miaziv $u$ khvorykh z ishemichnoiu kontrakturoiu stopy. Klinichna khirurhiia. 2002;(3):45-7. [In Ukrainian]. 